\title{
Plasmacytoid dendritic cells are increased in cerebrospinal fluid of untreated patients during multiple sclerosis relapse
}

\author{
Ana Leda F Longhini ${ }^{1 \dagger}$, Felipe von Glehn ${ }^{1,2 \dagger}$, Carlos Otávio Brandão ${ }^{1}$, Rosemeire FO de Paula ${ }^{1}$, Fernando Pradella ${ }^{1}$, \\ Adriel S Moraes', Alessandro S Farias', Elaine C Oliveira ${ }^{1,3}$, Juan G Quispe-Cabanillas', Cassiana Horta Abreu 1,2, \\ Alfredo Damasceno², Benito P Damasceno ${ }^{2}$, Konstantin E Balashov ${ }^{4}$, Leonilda MB Santos ${ }^{1 *}$
}

\begin{abstract}
The plasmacytoid dendritic cells (pDCs) express a high level of Toll-like receptor 9 (TLR-9), which recognizes viral DNA. Activated via TLR-9, pDCs also secrete large amounts of type I interferon which are involved either in stimulation or down regulation of immune response in multiple sclerosis (MS). In the present study, we determinate pDCs levels by flow cytometry in Cerebrospinal Fluid (CSF) and Peripheral Blood from MS patients in relapsing and in remitting phases of the disease, comparing with other non-inflammatory diseases (OND). We provide evidence that MS patients in relapse without any treatment have a significantly $(p<0.01)$ higher percentage of pDCs in CSF than do patients in remission or those with OND. No change in the percentage of pDCs was observed in the peripheral blood of any of these patients. The increase of pDCs in central nervous system during relapse may be explained either by a virus infection or a down regulatory process.
\end{abstract}

\section{Introduction}

The pathogenesis of multiple sclerosis (MS) is mainly driven by central nervous system-invading encephalitogenic CD4 $\mathrm{T}$ lymphocytes of both the Th1 and Th17 types. These effector cells can be downregulated by regulatory $\mathrm{T}$ lymphocytes [1]. One subset of dendritic cells, the plasmacytoid dendritic cells (pDCs), has been given particular emphasis due to its importance in stimulating or down regulating effectors $\mathrm{T}$ cells in MS [2].

These pDCs are present in the cerebrospinal fluid (CSF), leptomeninges and demyelinating lesions of patients with MS [3]. These cells express a high level of Toll-like receptor 9 (TLR-9), which recognizes viral DNA. Activated via TLR-9, pDCs secrete large amounts of type I interferon [4]. The use of type I interferon as an immunomodulator in the treatment of MS patients has proved beneficial for patients with the relapsing/ remitting form of MS (RRMS), and the production of

\footnotetext{
* Correspondence: leonilda@unicamp.br

+ Contributed equally

${ }^{1}$ Neuroimmunology Unit, Dept Genetics, Evolution and Bioagents, Biology

Institute University of Campinas - UNICAMP

Full list of author information is available at the end of the article
}

this cytokine by the pDCs may suggest an important immunomodulatory function of these cells.

In the present study, the concentration of pDCs in the CSF and peripheral blood of MS patients during relapsing and remitting phases of the disease was determined and compared to what is present in other noninflammatory neurological diseases (OND).

\section{Patients and Methods}

Peripheral venous blood (5 ml) and CSF (5-10 ml) samples were collected from patients with RRMS, as defined by the revised McDonald criteria [5]. The MS patients were divided into two groups: relapsing (six patients) and in remission (eleven patients). Moreover, samples were collected from 8 patients with other noninflammatory neurological diseases (OND). Relapse was defined as recent onset (within 1-7 days) of clinical neurological symptoms, but without any clinical or laboratorial signs of infection at the time of lumbar puncture. All patients included agreed to participate in the study, which was approved by the University of Campinas Committee for Ethical Research, and they signed a term

\section{C) Biomed Central}


Table 1 Demographic and baseline clinical characteristics of patients and controls

\begin{tabular}{ccccccc}
\hline & Patients \# & Age (years*) & Gender F/M & Time from first relapse (Years*) & CSF cells/ $\boldsymbol{\mu l}$ * & Oligoclonal Bands \\
\hline RRMS - Relapse & 6 & $34(30-47)$ & $4 / 2$ & $5(1-8)$ & $6(0-17)$ & $6+/ 0-$ \\
\hline RRMS- remission & 11 & $34(26-61)$ & $9 / 2$ & $3(1-8)$ & $3(1-23)$ & $8+/ 3-$ \\
\hline OND $^{* *}$ & 8 & $46(30-64)$ & $7 / 1$ & - & $2(0-5)$ & \\
\hline
\end{tabular}

*Median (range)

**Other Neurological Diseases

of Consent. The clinical characteristics of the patients are presented in Table 1.

Patients using corticosteroids or other immunosuppressive and immunomodulatory drugs at the time of investigation were excluded from the study. The group with OND consisted of eight patients with no clinical evidence of any inflammatory process in the central nervous system (CNS). Two patients had had an ischemic stroke, two patients had pseudotumor cerebri, one had psychiatric disorders, one had epilepsy, one had normal pressure hydrocephalus and one patient had post trauma headache.

\section{Flow Cytometry Analysis}

The proportion of pDCs (in \%) in relation to other mononuclear cells was determined by staining the CSF and peripheral blood mononuclear cells (PBMC) with anti-human BDCA2-mAb conjugated with APC (Miltenyi Biotec, Germany). Data were acquired for gating mononuclear cells using a BD FACSCanto cytometer (BD Biosciences, USA) and analyzed using BD FACSDiva software (BD Biosciences, USA). The $p$ value was determined using unpaired T-test.

\section{Results and Discussion}

The number of pDCs is significantly elevated in the CSF of patients in the relapse phase of untreated MS compared to patients in remission (Figure 1). Since there are no differences in the number of these cells neither in the PBMC nor in total number of cells in the CSF of the same patients, pDCs must selectively increase in the CNS during the relapse phase of disease. As far as we know, this is the first observation of such an increase in the percentage of pDCs in the CSF of MS patients in a specific phase of the disease. A previous study reported an elevated concentration of dendritic cells, mainly pDCs, in patients with infections and other inflammatory neurological diseases, including MS, but no mention was made of variations during different phases of the disease [6].

The ambivalent function of pDCs has been observed in experimental autoimmune encephalomyelitis (EAE), a model for studying MS. A recent report shows that they promote priming of autoimmune Th17 in EAE, whereas depletion of $\mathrm{pDC}$ prior to induction of the disease decreases its severity [7]. Another recent study has demonstrated that clinical signs of EAE are exacerbated considerably if the pDCs are depleted during the peak period of the disease [2]. Thus, pDC depletion significantly enhances the activation of CNS cells and the production of cytokines such as IL-17 and IFN- $\gamma$, but not peripheral CD4 T cells [2]. Recent study developed in the EAE model, demonstrated that the tolerogenic property of pDCs is associated with MHC class II molecule in the presenting of neuroantigen to CD4 $\mathrm{T}$ cells. This specific-antigen stimulation induces regulatory $\mathrm{T}$ cells, which results in the reduction of the disease severity [8]. Moreover, pDCs also produce indolamine 2, 3 dioxigenase (IDO), which is an enzyme activated by both type I and type II Interferon, and is involved in tryptophan catabolism. Its immunosuppressive effect is linked to the reduction of local tryptophan concentration and to the activation of regulatory $\mathrm{T}$ cells $[9,10]$.

Also of relevance is the impact of treatment with immunomodulators and the length of its use on the presence of pDCs in CSF. There is no significant difference in the percentage of pDCs in the CSF when we analyzed the group of MS patients treated and not treated with interferon beta IFN $\beta$ (data not shown), suggesting that the increase of $\mathrm{pDCs}$ is restricted to patients in relapse.

Although the exact function of pDCs in the CNS needs to be elucidated in future studies, the presence of pDCs during the phase of relapse may be explained either by a virus infection or by the regulation of inflammatory process. As the immune response evolves, the increase in the production of pro-inflammatory cytokines such as IFNs stimulates the secretion of IDO by pDCs, which in turn will activate regulatory $\mathrm{T}$ lymphocytes. This immunomodulatory response will probably contribute to the reduction of inflammation in the CNS, thus preparing this microenvironment for the remission phase of MS. 
A

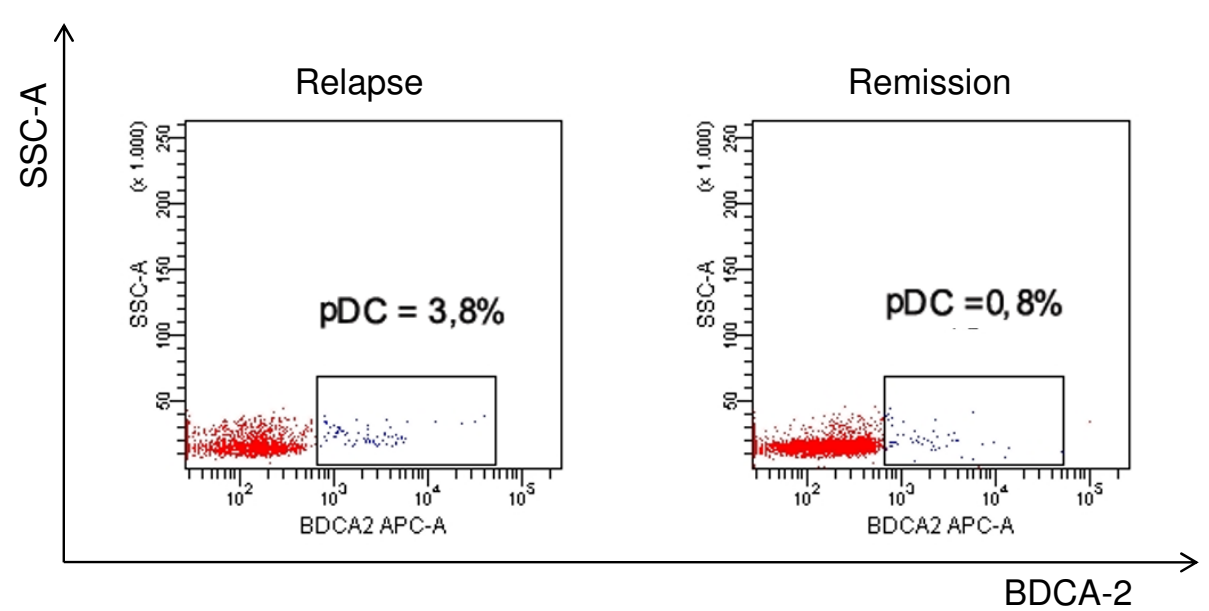

B

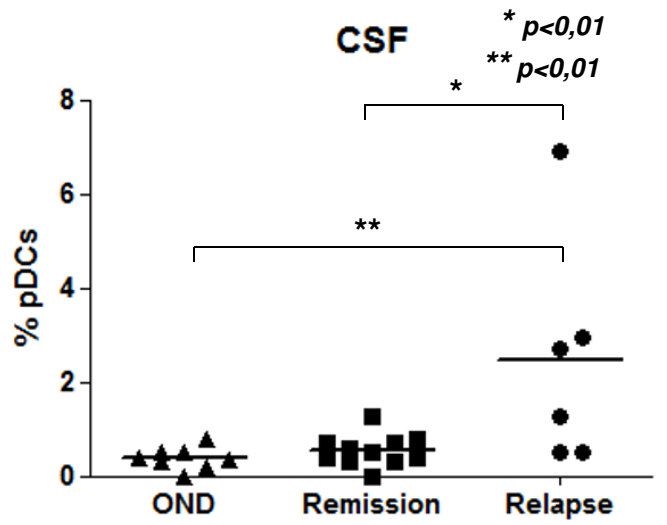

C

\section{Peripheral Blood}

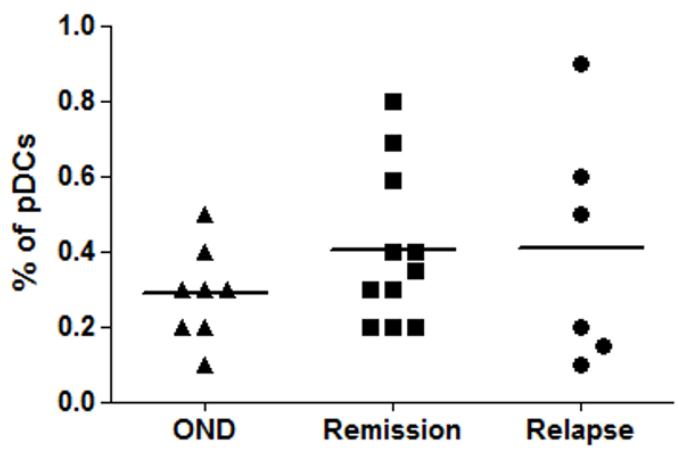

Figure 1 Concentration of pDCs in relation to other mononuclear cells in CSF and peripheral blood. (A) BDCA2 positive gated CSF cells, dot plot representative of MS patients in relapse and in remission. (B) Percentage of pDCs in CSF, with data points representing individuals of MS patients in relapse (6) and in remission (11) and in other neurological diseases (8). (C) Concentration of pDCs in peripheral blood, with data points representing individuals. Data are shown as median and the statistically significant differences are indicated by * $(p<0.01)$.

\section{Acknowledgements}

This study received financial support from the Brazilian government agencies FAPESP (Fundação de Amparo à Pesquisa do Estado de São Paulo), CNPq (Conselho Nacional de Desenvolvimento Científico e Tecnológico) and CAPES (Coordenação de Aperfeiçoamento de Pessoal de Nível Superior).

\section{Author details}

${ }^{1}$ Neuroimmunology Unit, Dept Genetics, Evolution and Bioagents, Biology Institute University of Campinas - UNICAMP. ${ }^{2}$ Dept of Neurology, University of Campinas - UNICAMP, Campinas, SP, Brazil. ${ }^{3}$ FATEC-Sorocaba, SP, Brazil.

${ }^{4}$ Robert Wood Johnson Medical School, New Brunswick, NJ, USA.

\section{Authors' contributions}

LMBS designed the study. FVG and COB selected the patients and collected the CSF and peripheral blood. ALFL, FVG, FP, ASM, RFOP, JGQC, ECO and ASF performed the experiments. ALFL made the flow cytometry analysis. $A L F L, A S F, F V G, L M B S$ and $C O B$ analyzed the results. ALFL, FVG, COB, ASF, $\mathrm{CHA}, \mathrm{AD}, \mathrm{BPD}, \mathrm{KEB}$ and $L M B S$ helped write the paper. All authors have read and approved the final version of the manuscript.

\section{Competing interests}

The authors declare that they have not competing interests. KEB has served as consultants for Biogen, TEVA Neuroscience, Bayer Healthcare, and EMD Serono.

Received: 22 November 2010 Accepted: 7 January 2011 Published: 7 January 2011

\section{References}

1. Ramagopalan SV, Dobson R, Meier UC, Giovannoni G: Multiple sclerosis: risk factors, prodromes, and potential causal pathways. Lancet Neurol 2010, 9:727-739.

2. Bayley-Bucktrout SL, Caulkins SC, Goings G, Fischer JAA, Dzionek A, Miller SD: Cutting edge: central nervous system plasmacytoid dendritic cells regulate the severity of dendritic cells in multiple sclerosis. J Immunol 2008, 180:6457-6461.

3. Lande R, Gava V, Serafini B, Giacomini E, Visconti A, Remoli ME, Severa M, Parmentier M, Ristori G, Salvetti M, Aloisi F, Coccia EM: Plasmacytoid dendritic cells in multiple sclerosis: intracerebral recruitment and 
impaired maturation in response to interferon-beta. $J$ Neuropathol Exp Neurol 2008, 67:388-401.

4. Moseman EA, Liang X, Dawson AJ, Panoskaltsis-Mortari A, Krieg AM, Liu YJ, Blazar BR, Chen W: Human plasmacytoid dendritic cells activated by CpG oligodeoxynucleotides induce the generation of CD4+CD25+ regulatory T cells. J Immunol 2004, 173:4433-4442.

5. Polman CH, Reingold SC, Edan G, Filippi M, Hartung HP, Kappos L,

Lublin FD, Metz LM, McFarland HF, O'Connor PW, Sandberg-Wollheim M, Thompson AJ, Weinshenker BG, Wolinsky JS: Diagnostic criteria for multiple sclerosis: 2005 revisions to the 'McDonald Criteria'. Ann Neurol 2005, 58:840-846.

6. Pashenkow M, Huang YM, Kostulas V, Haglund M, Sodestrom M, Link H: Two subsets of dendritic cells are present in human cerebrospinal fluid. Brain 2001, 124:480-492.

7. Isaksson M, Ardesjo B, Ronnblom L, Kämpe O, Lassmann H, Eloranta ML, Lobell A: Plasmacytoid DC promote priming of autoimmune Th17 cells and EAE. Eur J Immunol 2009, 39:2925-2935.

8. Irla M, Kuepfer N, Suter T, Lissilaa R, Benkhoucha M, Skupsky J, Lalive PH Fontana A, Reith W, Hugues S: MHC class II-restricted antigen presentation by plasmacytoid dendritic cells inhibits $\mathrm{T}$ cell-mediated autoimmunity. J Exp Med 2010, 207:1891-1905.

9. Bayas A, Stasiolek M, Kruse N, Toyka KV, Selmaj K, Gold R: Altered innate immune response of plasmacytoid dendritic cells in multiple sclerosis. Clin Expl Immunol 2009, 157:332-342.

10. Kwidzinski E, Bechmann I: IDO expression in the brain: a double-edge sword. J Mol Med 2007, 85:1351-1359.

doi:10.1186/1742-2094-8-2

Cite this article as: Longhini et al:: Plasmacytoid dendritic cells are increased in cerebrospinal fluid of untreated patients during multiple sclerosis relapse. Journal of Neuroinflammation 2011 8:2.

\section{Submit your next manuscript to BioMed Central} and take full advantage of:

- Convenient online submission

- Thorough peer review

- No space constraints or color figure charges

- Immediate publication on acceptance

- Inclusion in PubMed, CAS, Scopus and Google Scholar

- Research which is freely available for redistribution

Submit your manuscript at www.biomedcentral.com/submit
Ciomed Central 